\title{
Integrated Law Enforcement in Handling of Local Election (Pemilukada) Criminal Actions in 2018/2019
}

\section{Iwan $^{*}$ and Sri Kusriyah**}

*) Student of Master of Law, Universitas Islam Sultan Agung Semarang, and Kanit 1 Political Sat Intelkam Police Cirebon E-mail: sip2016d.iwan@gmail.com

$\left.{ }^{* *}\right)$ Faculty of Law Universitas Islam Sultan Agung

\begin{abstract}
.
The objectives of this research are: To find out and analyze integrated law enforcement in post-conflict local election 2018/2019 criminal cases. To find out and analyze the obstacles in the integrated law enforcement of the 2018/2019 post-conflict local election criminal acts and their solutions. The method used by researchers is juridical sociological approach to law and the specification in this research is including analytical descriptive. As for the sources and types of data in this study are primary data and secondary data obtained from literature studies. Based on the results of that research of Integrated Law Enforcement in Criminal Cases in the 2018/2019 Pemilukada is by the Police, Attorney General's Office and Panwaslu who are members of the Integrated Law Enforcement Center (Gakkumdu), by adjusting the criminal justice system as generally regulated in the KUHAP, including investigations by the Police, prosecution by Prosecutors and criminal decisions by the Court. The obstacle is due to the lack of criminal threats so that there are still many people who feel they are not deterred and want to take advantage of the existing situation without thinking about anything else, while in the law enforcement factor there is a lack of members or investigators who are truly competent in handling the case so that the investigation process a little constrained.
\end{abstract}

Keywords: Integrated Law Enforcement; Crime; Local Election.

\section{Introduction}

In the life of the nation and state, security is a determining factor in the life of the nation and the state of implementing a sovereign and authoritative government, which is the main condition that supports the realization of a just, prosperous, prosperous and civilized life in a civil society system based on Pancasila and the Constitution of the Republic of Indonesia. 1945 Indonesia. Domestically, the National Police carries out law enforcement efforts through the process of investigating and investigating criminal acts as regulated in Act No. 2 of 2002 concerning the Indonesian National Police. ${ }^{1}$

Act No. 10 of 2016 regulates the election of Governors, Regents and Mayors. Article 70 of Act No. 10 of 2016 also regulates campaign leave for Regional Heads (incumbents). Regional heads who wish to run for a second term must apply for leave during the campaign period for regional head elections. This has generated a lot of controversy, because it is considered to have implications for the running of government management that is not running optimally or as it should. In addition, regional heads are bound by an oath of office to carry out their duties fully. So,

\footnotetext{
1 Umar Ma'ruf, Ni Made Srinitri. Progressivity Of Criminal Handling Fraud And Disease By The Directorate of The General Criminal Researcher Of Central Java Regional Police (POLDA), Jurnal Daulat Hukum Volume 3 Issue 1, March 2020 ISSN: 2614-560X.
} 
when a regional head who wants to advance to the second term, the regional head does not complete his duties according to the term of office given to him, because the campaign leave period he carries out is a requirement for a candidate for Regional Head.

Direct regional head elections (Pemilukada) are one of the goals of decentralization within the framework of regional autonomy. Decentralization broadly includes two aspects, namely administrative decentralization and political decentralization. Changes in the system and model for regional head elections are basically part of the electoral reform agenda in Indonesia. The framework that underlies the electoral reform is not only to increase the accountability of local governments, but also to build a presidential system of government at the local level. Direct regional head elections mean restoring the basic rights of the people in the regions by providing complete authority in the context of democratic local political recruitment. In this context, the state provides opportunities for people in the regions to determine their own leaders. ${ }^{2}$

The implementation of this direct election has also caused several negative impacts, including (1) the costs incurred will be even greater (2) does not guarantee an increase in public participation in participating in the direct election process (3) it can also disrupt the process of government administration in each of them, each region that held the direct elections. To overcome the problems caused by the direct regional election, there is one way that can be done, namely by holding a joint regional head election between the first level regional elections and the second level Pemilukada, known as joint Pemilukada. First, joint regional elections can be held if the end of the governor's term coincides with the end of the term of office of regional heads in regencies/cities.

Regional head elections (Pemilukada) are a means of people's sovereignty to elect regional leaders who have legality and legitimacy. The simultaneous regional elections are the right momentum for the regions to get leaders who are in accordance with the people's wishes clearly and objectively. ${ }^{3}$

The investigation process is carried out by the National Police investigator within a maximum period of 14 days from the time the report is received from Bawaslu. So, 14 days from the receipt of the report from Bawaslu, the investigator must submit the results of the investigation along with the case files to the Public Prosecutor concerned. Investigators can correct files for a maximum of three days and then return them to the public prosecutor. A maximum of five days after the files are received, PU will submit the case files to the court. To facilitate the examination process of suspected election criminal violations. ${ }^{4}$

The objectives to be achieved in this research are as follows: To find out and analyze integrated law enforcement in post-conflict local election criminal cases in $2018 / 2019$. To find out and analyze the obstacles in the integrated law

\footnotetext{
2J. Prihatmoko, Joko. (2005.) Pemilihan Kepala Daerah Langsung; Filosofi, Sistem, dan Problema Penerapan di Indonesia: Yogyakarta: Pustaka Pelajar. p. 21.

${ }^{3}$ Achmad Sulchan and Adib Althof Rusydi. Simultaneous Regional Election Polemics in the Middle of the Covid-19 Pandemic, Jurnal Daulat Hukum Volume 3 Issue 4, December 2020 ISSN: 2614-560X.

${ }^{4}$ Rusmanto, The Role of Investigators in the Crime of Regional Head Elections, Journal of Law Unissula, Vol. 35 No. 2 (2019).
} 
enforcement of the 2018/2019 post-conflict local election criminal acts and their solutions.

\section{Research methods}

The method used by researchers isjuridical sociological approach to law and the specification in this research is including analytical descriptive. As for the sources and types of data in this study are primary data and secondary data obtained from literature studies.

\section{Results and Discussion}

\subsection{Integrated Law Enforcement in Criminal Cases in the 2018/2019 Pemilukada in Cirebon Regency}

One of the main pillars in any democratic system is the existence of a mechanism for channeling people's opinions periodically and continuously through general elections. General Election is a political mechanism to articulate the aspirations and interests of citizens in the process of electing some of the people to become leaders of the government. ${ }^{5}$

Pemilukada criminal law enforcement does not only involve law enforcement officials in the ordinary criminal justice system, but also involves post-conflict local election administering institutions, in this case Bawaslu and its staff. Investigation of suspected election crimes must first be made with reports/recommendations from the Provincial Bawaslu and Regency/Municipal Panwaslu. In this mechanism, allegations of electoral violations must first go through a study by Bawaslu and related ranking agencies. Where, if the results of the election supervisor's study conclude that there is a suspected election crime, the results of the study together with the election supervisor's recommendations are forwarded to the investigating police. Because it involves a number of institutions in the handling of election crimes, with the aim of equalizing the understanding and pattern of handling election crimes by Bawaslu, Police and prosecutors, an integrated law enforcement center (Sentra Gakumdu) have been established. Where, this institution is positioned as a forum to equalize views between the two institutions involved in handling election crimes. ${ }^{6}$

The important role of the Gakkumdu Center in handling election criminal offenses is to receive reports of Election violations at every stage of the holding of the Regional Head Election from the Panwaslu and the KPU. Technically, the Gakkumdu Center conducts research and studies through the case title mechanism for every violation report received from Panwaslu. So that in carrying out tasks at the Gakkumdu Center, it is mandatory to apply the principles of coordination, integration and synchronization both in the implementation of tasks that are internal and external in nature, in accordance with the principles of the Integrated

\footnotetext{
5 Napitupulu, Paimin. (2004). Peran dan Pertanggungjawaban DPR Kajian di DPRD Provinsi DKI Jakarta, Disertasi, Bandung : Alumni. p. 71.

${ }^{6}$ Gunarto and Eko Nuryanto. (2020). General Election Law Position In The Enforcement Of Criminal Law, Law Development Journal, Volume 2 No 2, June, (146 - 154).
} 
Criminal Justice System. So with this principle, every element in the Gakkumdu Center examines the incoming reports.

The Constitutional Court (MK) is expected to play a full role in maintaining the values of the constitution and democracy, so that the functions and duties of the Constitutional Court are positioned as: (1) the guardian of the constitution, (2) final interpreter of the constitution (final interpreter of the constitution) ), (3) the guardian of democracy, (4) protection of the constitutional rights of citizens (protector of citizens' constitutional rights), and (5) protection of human rights (protector of human rights). From August 13, 2003 to 2009, at least the Constitutional Court has tried general election result disputes (General election result dispute) a total of 45 cases consisting of 274 cases of the 2004 election and 71 cases consisting of the 2009 election of 657 cases, and 27 cases of head election disputes (dispute over the head of the election results). The Constitutional Court also accepted requests for disputes over the elections for President and Vice President in 2004 and 2009, one case each. So, the Constitutional Court is a legal doorstop in resolving election conflicts with a legal basis orientation and implementing democracy that has emerged in the Indonesian state with legal sanctions for violators of the Election Law. ${ }^{7}$

The public prosecutor after receiving the investigation result case file from the Police investigator, immediately studies and examines the case file, and within three days is obliged to notify the Police investigator whether the results of the investigation are complete or not. If the results of the investigation are not complete, the public prosecutor must return the case file to the investigator within three days, along with instructions on what to do to be completed.

Integrated Law Enforcement in Criminal Cases in the 2018/2019 Pemilukada is by the Police, Attorney General's Office and Panwaslu who are members of the Integrated Law Enforcement Center (Gakkumdu), by adjusting the criminal justice system as generally regulated in the KUHAP, including investigations by the Police, prosecution by Prosecutors and criminal decisions by the Court. Regulations and exceptions specifically for procedural law to resolve election crimes are regulated by Act No. 10 of 2016 concerning the Election of Governors, Regents and Mayors. The important role of the Gakkumdu Center in handling election criminal offenses is to receive reports of Election violations at every stage of the holding of the Regional Head Election from the Panwaslu and the KPU. Coordination between Bawaslu, Police, and the Attorney General's Office in resolving criminal acts of "money politics" against the Regional Head Election system, namely the Gakkumdu Center in handling election criminal offenses, is receiving reports of Election violations. Technically, the Gakkumdu Center conducts research and studies through the case title mechanism for every violation report received from Panwaslu. So that in carrying out tasks at the Gakkumdu Center, it is mandatory to apply the principles of coordination, integration and synchronization both in the implementation of tasks that are internal and external in nature, in accordance with the principles of the Integrated Criminal Justice System. Sentra Gakkumdu conducts research and studies through the case title mechanism for every violation

\footnotetext{
${ }^{7}$ Jawade, Hafidz. The Urgency to Strengthen the Role of the Constitutional Court in the Application of Election Sanctions in Indonesia, Jurnal Hukum, Vol 29, No 1 (2014).
} 
report received from Panwaslu. So that in carrying out tasks at the Gakkumdu Center, it is mandatory to apply the principles of coordination, integration and synchronization both in the implementation of tasks that are internal and external in nature, in accordance with the principles of the Integrated Criminal Justice System. Sentra Gakkumdu conducts research and studies through the case title mechanism for every violation report received from Panwaslu. So that in carrying out tasks at the Gakkumdu Center, it is mandatory to apply the principles of coordination, integration and synchronization both in the implementation of tasks that are internal and external in nature, in accordance with the principles of the Integrated Criminal Justice System.

According to the author, Integrated Law Enforcement in Criminal Cases in the 2018/2019 General Election is analyzed from a point of view by using law enforcement theory that the legal structure is based on Act No. 8 of 1981 covers, starting from the Police, the Attorney General's Office, Courts and Criminal Executing Bodies (Lapas). The authority of law enforcement agencies is guaranteed by law. So that in carrying out their duties and responsibilities apart from the influence of government power and other influences.

\subsection{Constraints in the Integrated Law Enforcement of the 2018/2019 Pemilukada Criminal Act in Cirebon Regency and the Solutions}

The law enforcement process for post-conflict local election criminal acts in terms of statutory regulations from the investigation, investigation, prosecution to trial examination in court is no different from other criminal acts regulated in accordance with the criminal procedure law in the Criminal Procedure Code, the only difference is that Bawaslu's involvement in accepting and finding irregularities In general election regulations that are suspected of being a criminal act, even though they play a role in that matter, Bawaslu does not have the authority to conduct investigations and investigations into general election crimes. Bawaslu is only authorized to resolve violations in the form of procedural deviations. Actually, according to the provisions of the Criminal Procedure Code, anyone who is aware of a criminal act can report it to the police, So in the implementation of the election, in fact, according to the provisions of the Criminal Procedure Code, not only Bawaslu has the right to report suspected general election crimes to the police.

Election observers and even members of the public can report. Moreover, an election criminal offense is not a complaint offense (a criminal act requiring a complaint), but an ordinary offense, while Article 108 paragraph (1) of the Criminal Procedure Code states - everyone who experiences, sees, witnesses, and/or becomes a victim of an incident which constitutes an act. a criminal has the right to file a report or complaint - to the investigator and/or investigator, both orally and in writing. Thus, both Bawaslu, election observers, and anyone who is aware of an incident which constitutes a criminal act of general election has the right to report to the police. When viewed from the applicable criminal procedural law, Bawaslu is not an institution that holds the monopoly to report general election crime to the police. So once again it can be seen that there is no difference in the settlement of general election crimes from investigation to examination in 
court. It is also important to note that the police can receive reports of election crimes not only from Bawaslu, but from anyone who is aware of an election crime, for example from election observers and other people.

After receiving a police report, it is obligatory to immediately conduct an investigation or investigation, as stated in Article 102 and Article 106 of the Criminal Procedure Code, Article 102 paragraph (1) of the Criminal Procedure Code states that an investigator who knows, receives a report, or a complaint regarding the occurrence of an event which can reasonably be suspected of being a criminal act is obliged to immediately carry out the necessary investigative action. Meanwhile, Article 106 of the Criminal Procedure Code states that investigators who know, receive reports or complaints from the public regarding the occurrence of an event which can reasonably be suspected of being a criminal act are obliged to immediately carry out the necessary investigative action required by the police. ${ }^{8}$

Constraints to the Integrated Law Enforcement of Criminal Actions for the 2018/2019 General Election include:

- Legal Substance

One of the keys to success in law enforcement is the mentality or personality of law enforcement. In the framework of law enforcement and law enforcement itself.

- Law enforcement

The legal function, mentality or personality of law enforcement officers play an important role, if the regulations are good, but the quality of the officers is not good, there is a problem. Law enforcers are role models in society, who should have certain abilities in accordance with the aspirations of society. Therefore, one of the keys to success in law enforcement is the mentality or personality of the law enforcer.

- Means or Facilities

Supporting Factors or supporting facilities include software and hardware, one example of software is education. If the laws and regulations are good and the mentality of the enforcer is good, but the facilities are inadequate, then law enforcement will not run properly.

- Public

Every member of society has at least some legal awareness, the problem that arises is the level of legal compliance. Citizens must know and understand the applicable laws and obey the applicable laws with full awareness of the importance and necessity of law for community life. The degree of community legal compliance with the law is one indicator of the functioning of the law in question.

- Culture

The function of culture in society is to regulate people to understand how they should act, act, and determine their attitudes when they relate to other people. In this case, culture includes the values that underlie applicable law, which values are abstract conceptions of what is considered good so that it is adopted, and what is considered bad so that it is avoided.

8Santoso , Topo. (2006). Tindak Pidana Pemilu ". Jakarta : Sinar Grafika. p. 60-64. 
Efforts to overcome obstacles in integrated law enforcement of post-conflict local elections in 2018/2019, namely:

- Improvement of personnel quality

Bawaslu itself always conducts evaluation and training of its members who handle general election crimes in order to improve the quality of its members.

- Utilizing available facilities and infrastructure

With regard to the lack of available facilities and infrastructure in handling criminal acts of post-conflict local elections, the Integrated Law Enforcement Center takes efforts to overcome it by maximizing every existing facility and infrastructure and for non-existing facilities and infrastructure, the Election Supervisory Body still submits a request to the central leadership to complete it. The facilities and infrastructure that do not yet exist in relation to enforcing election of criminal law.

- Socializing

The Chairperson of the General Election Agency in this case is also the Coordinator of the Legal Division and Eradication of the Election Supervisory Agency, revealed that his agency always socializes the public through seminars, advertisements in media that can be seen directly by the public, in order to create legal awareness the public that they also take part in general election supervision, including reporting on general election crimes.

According to the author, Constraints in the Integrated Law Enforcement of the 2018/2019 General Election of Local Election Crime and the solution is analyzed from a point of view by using the theory of legal effectiveness whether or not the law is effective in society is strongly influenced by three elements, namely elements of legal awareness, law obedience and law enforcement. . These three elements are closely related and have a relationship with each other in realizing legal effectiveness. The essence of the effectiveness of the law itself in the sense of legislation is the achievement of what the regulations aspire to (objectives).

\section{Closing}

Integrated Law Enforcement in Criminal Cases in the 2018/2019 Pemilukada is by the Police, Attorney General's Office and Panwaslu who are members of the Integrated Law Enforcement Center (Gakkumdu), by adjusting the criminal justice system as generally regulated in the KUHAP, including investigations by the Police, prosecution by Prosecutors and criminal decisions by the Court.

Constraints in the Integrated Law Enforcement of Criminal Actions in the 2018/2019 Pemilukada and the solution is due to the lack of criminal threats so that there are still many people who feel they are not deterred and want to take advantage of the existing situation without thinking about others, while in the law enforcement factor there is a lack of members or investigators who are truly competent in handling the case so that the investigation process is a little constrained. Efforts Made in Overcoming Barriers to Integrated Law Enforcement of Criminal Actions in the 2018/2019 Pemilukada, namely improving the quality of personnel, utilizing available facilities and infrastructure, and conducting socialization to the community. 
Further suggested To Bawaslu, the Police and the Attorney General's Office as well as all interested parties in the Pemilukada, it is necessary to increase cooperation and socialization between all parties in the common perception of Pemilukada Crime. For law enforcement institutions, especially the Attorney General's Office, they should budget for the allocation of funds for the settlement of Pemilukada criminal cases. Handling of post-conflict local election crimes requires seriousness in order to create clean and honest Pemilukada implementation, so the Gakkumdu Center needs to improve its performance, among others: a. Improve coordination between institutions; b. eliminating the sectoral ego of each institution; c. improve the quality of its personnel. Gakkumdu Center needs to make new breakthroughs in terms of handling election crimes considering the relatively short handling time.

\section{References}

\section{Journals}

[1] Achmad Sulchan and Adib Althof Rusydi. Simultaneous Regional Election Polemics in the Middle of the Covid-19 Pandemic, Jurnal Daulat Hukum Volume 3 Issue 4, December 2020 ISSN: 2614-560X.

[2] Gunarto and Eko Nuryanto. (2020). General Election Law Position In The Enforcement Of Criminal Law, Law Development Journal, Volume 2 No 2, June, (146 - 154).

[3] Jawade, Hafidz. The Urgency to Strengthen the Role of the Constitutional Court in the Application of Election Sanctions in Indonesia, Jurnal Hukum, Vol 29, No 1 (2014).

[4] Rusmanto, The Role of Investigators in the Crime of Regional Head Elections, Journal of Law Unissula, Vol. 35 No. 2 (2019).

[5] Umar Ma'ruf, Ni Made Srinitri. Progressivity Of Criminal Handling Fraud And Disease By The Directorate Of The General Criminal Researcher Of Central Java Regional Police (POLDA), Jurnal Daulat Hukum Volume 3 Issue 1, March 2020 ISSN: 2614-560X.

\section{Books}

[1] J. Prihatmoko, Joko. (2005). Pemilihan Kepala Daerah Langsung; Filosofi, Sistem, dan Problema Penerapan di Indonesia: Yogyakarta: Pustaka Pelajar.

[2] Napitupulu, Paimin. (2004). Peran dan Pertanggungjawaban DPR Kajian di DPRD Provinsi DKI Jakarta, Disertasi, Bandung: Alumni.

[3] Santoso, Topo. (2006). Tindak Pidana Pemilu". Jakarta: Sinar Grafika.

[4] Ali, Zainudin.(2014). Metode Penelitian Hukum, Jakarta: Sinar Grafika. 